\title{
Porcelain Laminate Veneer Applications in Upper Anterior Region: Case report
}

\section{Üst Ön Bölgede Porselen Laminate Veneer Uygulamaları Olgu Bildirimi}

\author{
(D) Zeynep Buket KAYNAR, iD Nazmiye DÖNMEZ
}

Bezmiâlem Vakıf University Faculty of Dentistry, department of Restorative Dental Treatment, İstanbul, Turkey

\begin{abstract}
Recently, effects of rapidly developing technology have been seen in the dentistry. Advances in materials enable minimally invasive treatments in which dental tissue is preserved in order to provide esthetics.. Porcelain laminate veneer technique, one of the minimally invasive treatments, is the most popular treatment today. Porcelain laminate veneers stand out with having translusity close to tooth and high biocompatibility properties. In this case report, stages of porcelain laminate veneer technique are described in detail.
\end{abstract}

Keywords: Porcelain, laminate, esthetic

\section{ÖZ}

Son zamanlarda hızla gelişen teknolojinin dişhekimliği alanında da yansımaları görülmektedir. Materyallerdeki gelişmeler estetiğin sağlanabilmesi için diş dokusunun korunduğu minimal invaziv tedavileri mümkün kılmaktadır. Minimal invaziv tedavilerden biri olan porselen laminate veneer tekniği günümüzde en popüler olan tedavi şeklidir. Porselen laminate veneerler dişe yakın translüsite göstermeleri ve yüksek biyouyumluluk özellikleriyle öne çımaktadır. Bu olgu sunumunda, porselen laminate veneerlerin yapım aşamaları ayrıntılarıyla anlatılmaktadır.

Anahtar Sözcükler: Porselen, lamina, estetik

\section{Introduction}

Esthetic problems in the front area are usually caused by gaps between teeth, discoloration, anomalies of shape, structure and position disorders that occur due to various reasons. These aesthetic problems can be treated with composite or porcelain laminate veneers, complete ceramic restorations, vital and devital whitening methods and combined methods. Porcelain laminate veneer technique is a conservative method and can meet esthetic expectations at a high rate due to its longer life than composite laminate veneers and it results in more esthetic appearance compared to composite laminate veneers $(1,2)$.

In this case report, all stages of treatment, involving porcelain laminate veneer, of a female patient, who was admitted to our clinic with the request of removing the esthetic complaints on her front teeth, was described

\section{Case Report}

A 30-year-old female patient was admitted to our clinic because the old composite restorations on her upper front incisors did not meet her esthetic expectations (Figure 1).

An intra-oral examination of the patient revealed that old restorations had lost edge alignment and secondary bruises had formed. After occlusion control, radiographic examination and evaluation of the patient's habits, it was decided to perform laminate veneer restorations on teeth 11-12-21-22 using lithium disilicate glass ceramic material. First, the consent form was taken from the patient. The tooth color was determined by using the Vitapan Classical Shade Guide (Vita Zahnfabrik, Germany) in daylight before the teeth were introduced to the preparation stage. Before starting the preparation, local anesthesia was performed to

Address for Correspondence: Zeynep Buket KAYNAR, Bezmiâlem Vakıf University Faculty of Dentistry, 
the related teeth. After all of the old composite restorations were removed, the rotten tissues were cleaned $(1,3)$. Preparations were made using chamfer frez (G\&Z Instruments, Austria), just above the gum, approximately $0.5 \mathrm{~mm}$ wide (Figure 2). After gingival retraction cord with the number \#00 (Ultradent, A.B.D.) was placed, final cutting was done and lacquer discs (Sof-Lex, 3MEspe, A.B.D.) were used to ensure smooth cutting. Plaster was transferred to the model with occlusal records by making measurement with additional type of silicone measuring agent (Variotime, Kulzer, Germany) after the preparation was completed.

The cementation process was performed using the Variolink Esthetic LC (Ivoclar,Vivadent, Liechtenstein) set. To check the color harmony before starting the simentation process, the color selection of the bonding cement with the testing cement was made. To the inner surface of the veneers, $10 \%$ hydrofluoric acid (Ultradent, A.B.D.) was applied for 20 seconds, then washed, and then dried with veneers air spray. Then cement (Monobond Plus, Ivoclar Vivadent, Liechtenstein) was applied to the veneers for 60 seconds. To teeth surfaces, $37 \%$ phosphoric acid (Total Etch, Ivoclar Vivadent, Liechtenstein) was applied for 15 seconds, then washed and dried. Then bonding agent was applied to all tooth surfaces and polymerized with $20 \mathrm{sec}$ light according to the manufacturer's instructions. The bonding cement suitable for tooth color was applied to the inner surface of the veneers and placed on the tooth surface with a slight finger

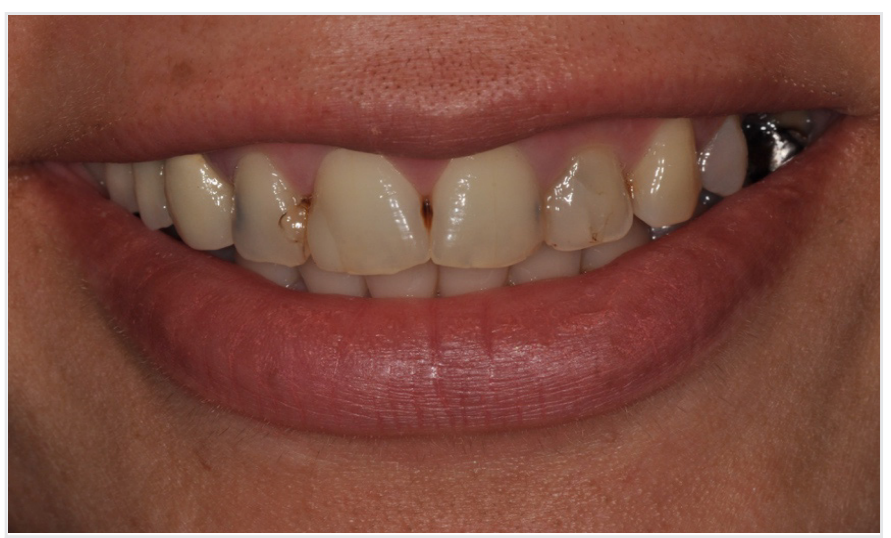

Figure 1. Intra-oral image of the patient before treatment

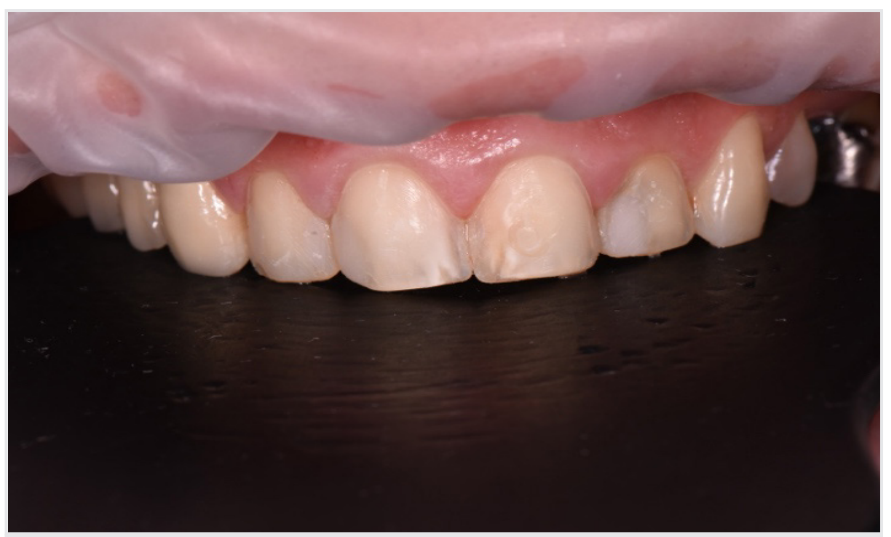

Figure 2. The image of the prepared teeth pressure and initial polymerization was made with a LED light source (Valo, Ultradent, A.B.D) for $3 \mathrm{sec}$. The residue of the bonding cement was removed, the gingival sulcus was checked with dental floss, glycerin was applied to the gingival margin area and polymerization was completed by applying $40 \mathrm{sec}$ light to each area (Figure 3). Edge alignment of laminate veneers was re-checked with eye and sond and occlusal alignment was rechecked with articulation paper (Figure 4, 5). The patient was called to control laminate veneers at the end of one year. Surface roughness, border alignment and coloration of laminate veneers, and secondary caries were evaluated (Figure 6).No problems were observed between restorations and teeth in terms of edge alignment. The restorations were determined to be esthetically good.

\section{Discussion}

Both composite and porcelain laminate veneer restorations can be applied in esthetic applications in the anterior region. Porcelain laminate veneer causes less material removal from the surface of the teeth, shows better color stability and biocompatibility and has more esthetic appearance compared with composite laminate veneer and it is a quite frequently used type of restoration $(1,2)$.

Although more successful results are obtained with porcelain laminate veneers in terms of meeting esthetic expectations; they require more precise work, their repair is more difficult, they

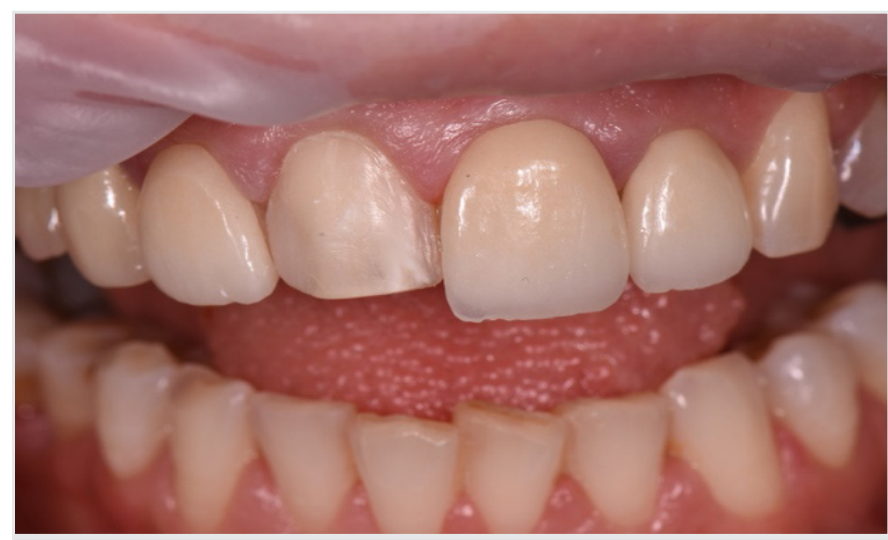

Figure 3. Cementation phase

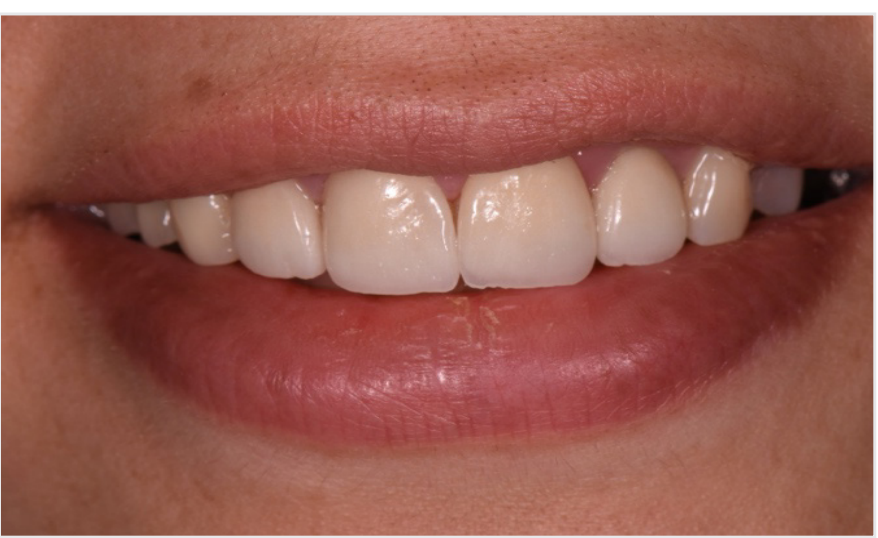

Figure 4. Post-cementation image of porcelain laminate veneers 
are more sensitive to breakage and their cost is higher compared with composite veneers which are among the disadvantages of porcelain laminate veneers $(4,5)$.

Direct composite veneer applications may be preferred due to lack of laboratory stages, fast results and low cost in patients whose economic status is taken into account (6). However, although composite laminate veneers provide an acceptable esthetic result, they cannot provide as much light transmission as porcelain laminate veneers.

When evaluated in terms of microleakage and edge alignment, it is accepted that porcelain laminate veneers are superior to composite veneers $(7,8)$. In addition to these, porcelain laminate veneers have more resistance to erosion, show higher attachment to enamel and are more resistant to stress and shear forces compared with composite veneers $(8,9)$. These are the reasons why porcelain laminate veneers are more preferred.

Compared to full ceramic crowns, they are preferred because they require a smaller amount of cutting.

The most important stage affecting the success of porcelain laminate veneers in the long term is adhesive cementation. The structure and properties of the adhesive used should be well known and applied accordingly. When light-activated adhesive systems and dual cure systems are compared, light-activated

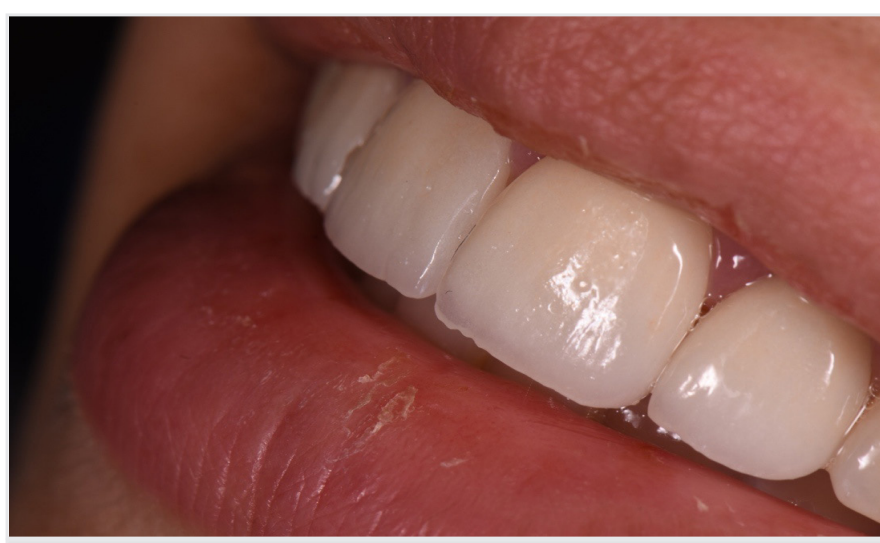

Figure 5. Finished porcelain laminate veneers

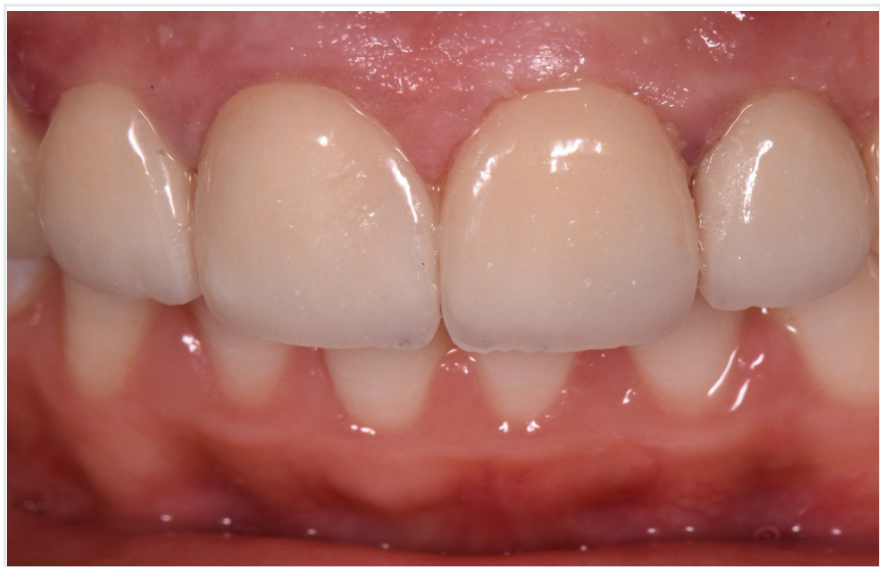

Figure 6. Image of porcelain laminate veneers at the end of 12 months follow-up adhesives have a prolonged curing times and very good color stability which are among the reasons why they are preferred more than dual cure systems (10). During the cementation phase, it is also very important to remove the residue of the bonding cement which can cause excessive irritation in gums.

Porcelain laminate veneer restoration is a conservative approach resulting in good esthetic results, especially in patients with limited pathology to enamel tissue in case of determining correct indication in esthetic rehabilitation of the anterior region and of careful performing the application stages.

\section{Ethics}

Informed Consent: First, the consent form was taken from the patient.

Peer-review: İnternally peer-reviewed.

\section{Authorship Contributions}

Concept: Z.B.K., N.D., Design: Z.B.K., N.D., Data Collection or Processing: Z.B.K., N.D., Analysis or Interpretation: Z.B.K., N.D., Literature Search: Z.B.K., N.D., Writing: Z.B.K., N.D.

Conflict of Interest: No conflict of interest was declared by the authors.

Financial Disclosure: The authors declared that this study received no financial support.

\section{References}

1. Gürel G. The science and art of porcelain laminate veneers: London: Quintessence; 2003.

2. Ersöz E, Eskitaşçı̆̆lu G, Günyaktı N. Laminate veneerlerde stres dağılımının incelenmesi. Ankara Ü Diş Hek Fak Dergisi 1995;22:237-43.

3. Barceleiro MdO, Miranda M, Dias K, Sekito T. Shear bond strength of porcelain laminate veneer bonded with flowable composite. Oper Dent 2003;28:423-8.

4. Yuzugullu B, Tezcan S. Renk değişimine ve erozyona uğramış dişlerde laminat veneer restorasyon seçeneklerinin endikasyon bakımından karşılaştırılması. Cumhuriyet Üniversitesi Diş Hekimliği Fakültesi Dergisi 2005;8:133-7.

5. Meijering A, Roeters F, Mulder J, Creugers N. Patients's satisfaction with different types of veneer restorations. J Dent 1997;25:493-7.

6. Chiche G. Esthetic of anterior fixed prosthodontics. Quintessence international (Berlin, Germany : 1985) 1994;128-40.

7. Lacy AM, Wada C, Du W, Watanabe L. In vitro microleakage at the gingival margin of porcelain and resin veneers. J Prosthet Dent 1992;67:7-10.

8. Kursoglu P, Motro PFK, Yurdaguven H. Shear bond strength of resin cement to an acid etched and a laser irradiated ceramic surface. J Adv Prosthodont 2013;5:98-103.

9. Peumans M, Van Meerbeek B, Lambrechts P, Vanherle G. Porcelain veneers: a review of the literature. J Dent 2000;28:163-77.

10. Linden J, Swift Jr E, Boyer D, Davis B. Photo-activation of resin cements through porcelain veneers. J Dent Res 1991;70:154-7. 